Research Article

\title{
Interaction between Cowpea Aphid-Borne Mosaic Virus Isolates and Its Effect on Passion Fruit Woodiness Disease on Passiflora edulis Sims and Passiflora ligularis Juss
}

\author{
Lucy J. Kiptui $\mathbb{D}^{1},{ }^{1}$ Faith J. Toroitich, ${ }^{1}$ Dora C. Kilalo, ${ }^{2}$ and Meshack Obonyo ${ }^{3}$ \\ ${ }^{1}$ Department of Biological Sciences, Egerton University, Njoro, Kenya \\ ${ }^{2}$ Department of Plant Science and Crop Protection, University of Nairobi, Nairobi, Kenya \\ ${ }^{3}$ Department of Biochemistry and Molecular Biology, Egerton University, Njoro, Kenya \\ Correspondence should be addressed to Lucy J. Kiptui; lujekip@gmail.com
}

Received 18 September 2020; Revised 16 November 2020; Accepted 26 November 2020; Published 7 December 2020

Academic Editor: Gábor Kocsy

Copyright (C) 2020 Lucy J. Kiptui et al. This is an open access article distributed under the Creative Commons Attribution License, which permits unrestricted use, distribution, and reproduction in any medium, provided the original work is properly cited.

In East Africa, passion fruit woodiness disease is caused by potyviruses, among which are Cowpea Aphid-Borne Mosaic Virus (CABMV) and Uganda Passiflora Virus (UPV). Previous studies suggest that synergistic interaction of viruses causes mild or severe outcomes of the disease. However, mixed infections of these viruses have not been documented. The aim of this study was to determine the effects of the interaction between two $C A B M V$ isolates causing passion fruit woodiness disease in Kenya. Healthy plants were mechanically inoculated at six-leaf stage. Four treatments were used: $C A B M V$ isolate 1, $C A B M V$ isolate 2, mixture of the two isolates, and noninoculated control. The test plants were maintained in a screen house, and data on symptom severity and rate of disease development were recorded. ELISA test was conducted to confirm virus presence and distribution. The results indicate that the $C A B M V$ isolates used are systemic. There were various differences in disease progression, which was faster in the sweet passion variety than in the purple variety. However, the latter had a higher disease severity. Coinfected plants expressed severe symptoms compared to the singly infected ones, indicating synergistic interaction between the viral isolates. This implies that coinfection has adverse impact resulting in higher economic losses.

\section{Introduction}

Passion fruit is an economical viable crop, grown in Kenya, to improve livelihoods of small holder farmers. The crop is among the top three exported fruits. It earns Kenya about Sh1.64 billion annually in foreign exchange [1]. Passiflora ligularis (sweet passion) and Passiflora edulis (purple passion) are the two major species grown in Kenya. These varieties are susceptible to CABMV [2]. The key species commonly grown for export in Kenya is Passiflora edulis. Viral diseases in passion fruit production are of great concern because they affect the fruit quality and quantity and the orchard age wherever the fruit is grown [3]. In Kenya, woodiness disease is prevalent in passion fruit orchards and can cause losses of up to $90 \%$ or even as high as $100 \%$ in the presence of other fungal diseases such as fusarium wilt [4]. Virus pathogens responsible for woodiness disease include Cowpea AphidBorne Mosaic Virus (CABMV), Passion Fruit Woodiness Virus (PWV), and Uganda Passiflora Virus (UPV) $[5,6]$. However, country-wide surveys carried out in 2008-2010 in Kenya showed that Passion Fruit Woodiness Virus (PWV) was not present and instead indicated a high prevalence and incidence of CABMV in passion fruit orchards in Kenya [3]. It had earlier been assumed that the variation of disease symptoms observed was due to a different novel potyvirus, like UPV, but sequencing work done on woodiness virus isolates in Kenya by Kilalo (2012, unpublished) indicated the presence of CABMV only in the passion plants showing different symptoms. Thus, there is an assumption that several CABMV isolates or strains could exist in the country. 
It is common to find multiple viruses infecting a single host plant [7], and in such cases, the effects of the disease are compounded [8]. Viral coinfection may lead to symptoms exacerbation or plant protection depending on whether the virus interaction is synergistic or antagonistic [9]. The effects of synergistic interaction have huge economic and epidemiological implications because they aggravate virus symptoms consequently causing significant production losses [10].

While viruses occurring in the same host interact with each other to influence plant host interaction [8], most research has focused on their individual effects. However, considering that mixed infections have a greater impact on productivity, they deserve attention too [11]. In several other commercial crops such as maize, pepper, and watermelons, synergy between potyviruses in mixed infections has been widely reported [12]. However, information on mixed-virus infections and their effects on passion fruits is limited.

When in a mixture, viruses may recombine and evolve, producing more virulent strains which differ from known populations. This necessitates the need for frequent identification of emergent viruses and strains [8]. Therefore, the development of effective disease control strategies and diagnostic tools requires an informed knowledge on disease development. The interest of this research was to test the effects of interaction between two CABMV isolates that cause woodiness disease in Kenya on type of symptoms induced and symptom severity.

\section{Materials and Methods}

2.1. Infected Plant Materials (Virus Inocula). Plant leaves showing passion fruit woodiness disease symptoms were obtained from diseased plants maintained in a greenhouse at the University of Nairobi, College of Agriculture and Veterinary Sciences and farmers' field in Embu where previous collections had been made. The plants were tested for the presence of CABMV using ELISA. Only the farmers' field samples with CABMV were used in this study. Deep sequencing of the samples maintained in the green house at the University of Nairobi and in the farmers' field had revealed the presence of CABMV and no other potyvirus [13]. Virus obtained from the farmers' field was named virus isolate 1, while that obtained from the greenhouse was named virus isolate 2 . These two woodiness disease causing viruses induced distinct symptoms and severity to passion fruit plants.

2.2. Passion Fruit Seedlings. The seeds of P. ligularis and $P$. edulis were obtained from Nakuru market and sown in nursery bed protected by screen nets and maintained underrequisite agricultural practices such as constant watering and weed control. After two months, the seedlings were transplanted into pots containing a mixture of sterilized gravel, farmyard manure, and soil in ratio of $2: 1: 1$, and $70 \mathrm{~g}$ diammonium phosphate fertilizer. Thereafter, the plants were maintained in a glass house. At four-leaf stage after emergence, the plants were tested for CABMV presence using RT-PCR, following the manufacturer's protocol (Invitrogen, California).

Briefly, RNA was extracted from the leaves using ZR plant RNA miniprep $\mathrm{kit}^{\mathrm{TM}}$, following the manufacturer's instructions (Zymo Research, USA). Thereafter, cDNA was synthesized using the RT-PCR SuperScript ${ }^{\mathrm{TM}}$ III Reverse Transcriptase 1st-Strand cDNA kit (Invitrogen, California), following the manufacturer's protocol. The primer used in this synthesis is Reverse $5^{\prime}$-CTGCTGAGGAATTTAAGAGACAAG-3'. The cDNA obtained was ready for use in a PCR downstream. A total of $20 \mu \mathrm{L}$ of the PCR reaction mixture was used for each sample to amplify CABMV and UPV using the cDNA synthesized strands. The primer sequences for Cowpea Aphid-Borne Mosaic Virus were Forward 5'-GATGCAGGCAAGGATAAAGAAAAG-3' and Reverse $5^{\prime}$-CTGCTGAGGAATTTAAGAGACAAG- $3^{\prime}$ position $131 / 739$ amplifying a 628 bp product, a partial coat protein gene for CABMV. The Uganda Passiflora Virus primer sequences used were Forward $5^{\prime}$-GCACGAAATTCAAGAATACCTTAG- $3^{\prime}$ and Reverse 5'-GACTTCATAAAATCAAATGAGTA-3' position 558/1039 amplifying a 772 bp product, a partial coat protein gene of UPV. This was done to ensure that the seedlings were free from all viruses causing woodiness disease in East Africa. The mixture was made of $7.75 \mu \mathrm{L}$ sterile distilled water, $0.25 \mu \mathrm{L}$ Taq polymerase enzyme, $0.5 \mu \mathrm{L} \mathrm{F}$ primer, $0.5 \mu \mathrm{L} R$ primer, $5 \mu \mathrm{L}$ PCR buffer, $1 \mu \mathrm{L}$ DNTP, and $2 \mu \mathrm{L}$ cDNA. The PCR profile consisted of an initial denaturing step at $94^{\circ} \mathrm{C}$ for 5 minutes, followed by 35 cycles of $94^{\circ} \mathrm{C}$ for 30 -second denaturation, $58^{\circ} \mathrm{C}$ for 30 -second annealing, and $72^{\circ} \mathrm{C}$ for 45 second extension, followed by a $72^{\circ} \mathrm{C}$ final extension for 7 minutes, and a final hold step at $4^{\circ} \mathrm{C}$. The UPV primers were annealed at $48^{\circ} \mathrm{C}$ for 1 minute. The PCR products were then separated on a $1.5 \%$ agarose gel. Virus-free test plants were then used in the virus transmission test.

2.3. Virus Transmission Test. The experiment was carried out in a completely randomized design using 10 replicates per treatment. Four treatments (CABMV isolate 1, CABMV isolate 2, a mixture of the two isolates, and a buffer only for negative control) were used. Transmission test was carried out based on the procedure by Freitas and Rezende [2] as follows. Single-virus extracts from infected plants were prepared by grinding infected leaves in phosphate buffer at a ratio of 1:10 (tissue weight: buffer volume). Mixed-virus inocula were then prepared by grinding equal weights of the leaves infected with woodiness virus in phosphate buffer. Carborundum powder was dusted onto two leaves per plant and the virus sap rubbed to it using the forefinger. The inoculated leaves were washed gently with distilled water after 5 minutes. Data on disease symptoms was collected once weekly for eight weeks after inoculation. The disease severity was measured based on a 1 to 5 scale, which was slightly modified from Novaes and Rezende [14] as follows: plants without mosaic symptoms and leaf deformations and with good development of leaves (1), those with slight symptoms ( $25 \%$ of the leaf area with small mosaic) (2), those with moderate symptoms with mild mosaic and no leaf 
deformation ( $\sim 50 \%$ of the leaf area with mosaic) (3), those with strong symptoms ( $75 \%$ of the leaf area with mosaic) (4), and those with leaves with severe mosaic, blisters, and leaf deformations and later systemic necrosis to death (5).

2.4. Determination of the Presence and Distribution of $C A B M V$ Isolates. ELISA test was done twice in order to elucidate whether two different viruses causing woodiness disease occupied the same niche in commonly grown Kenyan variety. The presence of potyvirus in plant parts (stems, leaves, and roots) was first confirmed with general potyvirus antisera using Antigen-Coated-Plate ELISA (ACP-ELISA) as per the procedure of Clark and Adams [15]. This was to confirm whether there were other potyviruses other than CABMV. Thereafter, specific CABMV antisera (DAS-ELISA) was used to determine/confirm the presence of the virus within the test samples and especially those that tested positive for the general potyvirus test. The ELISA kits (DSMZ Institution for Microbiology, Germany) were used as per the manufacturers' instructions. In total, the roots, stem, and leaves for four plant samples showing positive virus symptoms were used for each treatment.

\subsection{Test for General Potyvirus Presence in the Samples.} The presence of potyviruses was conducted according to the procedure of Clark and Adams [15]. The roots, stem, and leaves of each test plant were crushed in extraction buffer. Thereafter, $200 \mathrm{ul}$ aliquots of test samples were added to the wells in duplicate. The plates were then incubated overnight at $4^{\circ} \mathrm{C}$. The plates were washed in PBS-Tween. Blocking was done to the wells by adding $200 \mathrm{ul}$ of PBS-Tween containing $2 \%$ skimmed milk to each well and incubating for 30 minutes at $37^{\circ} \mathrm{C}$. The blocking solution was removed, and the plates were tapped dry. Monoclonal antibody was added to the wells after diluting it in a conjugate buffer at a ratio of $1: 1000$. Incubation was then done at $37^{\circ} \mathrm{C}$ for 30 minutes followed by washing in PBS-Tween three times. RAM-AP was diluted in a conjugate buffer at a ratio of $1: 1000$; then aliquots of $200 \mathrm{ul}$ were added to each well before incubation for an hour at $37^{\circ} \mathrm{C}$. The plates were washed with washing buffer 3 times after the incubation period. After drying the plates, P-nitrophenyl phosphate $(1 \mathrm{mg} / \mathrm{ml})$ was added to the wells, and the plates were incubated at $37^{\circ} \mathrm{C}$ for 30 to 60 minutes.

2.6. Test for $C A B M V$ in the Samples. The presence of CABMV was tested following the procedure conducted by Clark and Adams [15]. The wells were coated with CABMV antibody diluted in coating buffer at a ratio of $1: 1000$ and incubated at $37^{\circ} \mathrm{C}$ for 4 hours. Thereafter, the plates were washed using PBS-Tween and blotted dry. This washing step was repeated thrice. The plant parts (roots, stem, and leaves) were ground in extraction buffer $(0.02 \mathrm{M}$ phosphate buffer, $\mathrm{pH}$ 7.4) separately at a ratio of $1: 20$ and then sieved through cheesecloth to extract the virus [16]. An aliquot $(200 \mathrm{ml})$ of the test samples was added to duplicate wells. Since the test was done in duplicate, samples with mean absorbance values more than two times the average of the negative control were considered positive.

2.7. Data Analysis. A completely randomized design was used in this study. Data collected was analyzed by one-way analysis of variance (ANOVA) PROC GLM, using SAS (9.7) to determine the difference in the average values of disease symptoms severity among the treatments. The most susceptible passion fruit variety was determined by comparing their mean severity score. The means were compared using LSD test at $P=0.05$ significance.

\section{Results}

As a preliminary experiment, 5-month-old test plants were used and only 2 plants per treatment developed the disease symptoms. This rendered the trial unsuccessful. For this reason, this study was conducted using younger plants at sixleaf stage.

All the test plants used for the study were negative for CABMV on RT-PCR test prior to inoculation (Figure 1). Plants treated with CABMV isolate 1 only were the first to show initial disease symptoms after 7 days of inoculation, while those inoculated with virus isolate 2 only showed symptoms 10 days after inoculation and those inoculated with a mixture of the two viruses showed symptoms 14 days after inoculation.

Virus infected plants exhibited typical symptom characteristics of passion fruit woodiness disease which are leaf mosaic and yellowing, leaf puckering, leaf blisters, stunted growth, and hardening of the leaves and stem (from the tip). However, the intensity of the symptoms varied for each virus treatment and plant variety used.

Coinfected plants presented more severe symptoms compared to singly infected ones. In P. ligularis variety, coinfection resulted in increased intensity of mosaic symptoms, leaf puckering, followed by intense chlorosis and leaf curling, whereas in $P$. edulis, coinfection resulted in increased leaf rolling, puckering, and blisters formation. Mosaic, reduced leaf size, and severely deformed apical leaves and vines were also observed. In addition, buds formed at the tip were crinkled, and infected leaves dropped after rapid yellowing (Figure 2).

Those infected with singly virus isolate 1 showed vein clearing, deformed leaves, blisters, and golden mosaic. Single inoculation with virus isolate 2 induced rugose leaves with diffused mosaic and leaf blisters (Figure 2). Coinfection resulted in the highest severity score of 3.2679 which was significantly different $(P<0.05)$ from the singly infected viruses (2.9107 and 2.8393) (Table 1). For each virus treatment, disease severity increased with time (Figure 3 ).

There was a significant difference $(P<0.05)$ in varietal susceptibility to the viruses. The purple $(P$. edulis) variety had a mean severity score of 2.65 ; thus it was more susceptible than the sweet passion ( $P$. ligularis) variety whose score was 2.14. Woodiness disease severity on $P$. edulis variety was significantly higher relative to the $P$. ligularis variety (Table 2). 


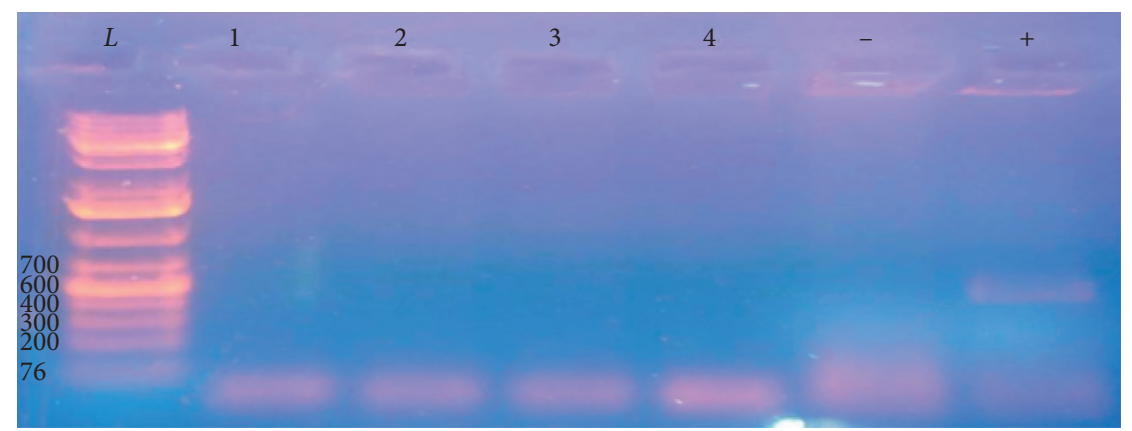

FIGURE 1: PCR amplification products of CABMV; 1, 2, 3, and 4 are the first four seedlings testing negative for CABMV. Negative control (-) is a sample from disease-free seedlings. Band size was compared with a $1 \mathrm{~kb}$ ladder $(\mathrm{L})$. The positive control (+) formed a band at $650 \mathrm{bp}$, which is the expected size for CABMV. It was obtained from diseased plant maintained in a screen house. All the seedlings tested showed similar results.

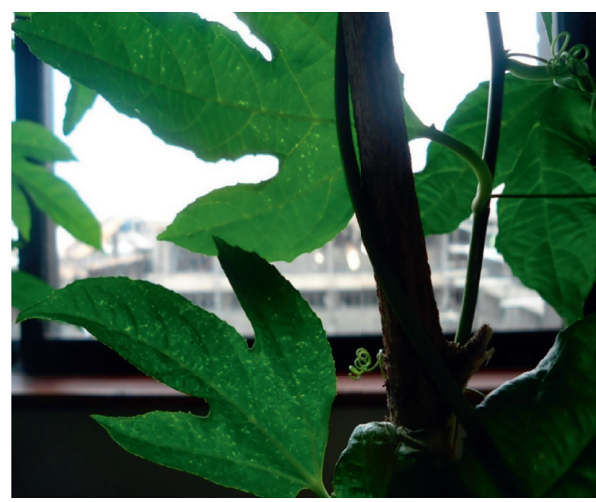

(a)

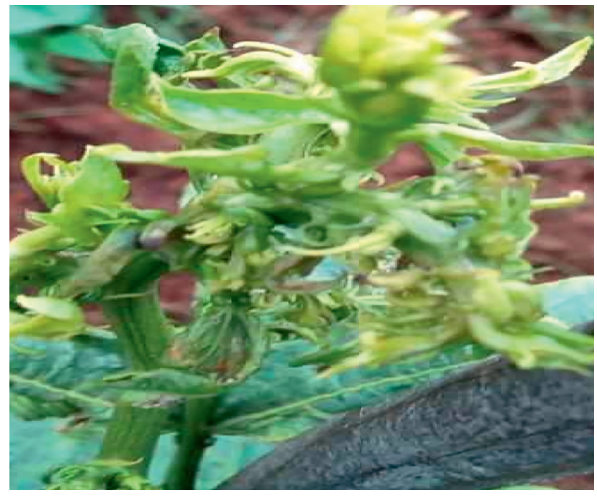

(c)

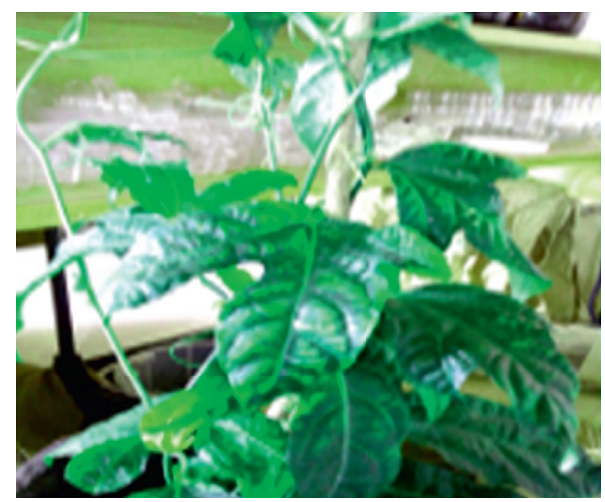

(b)

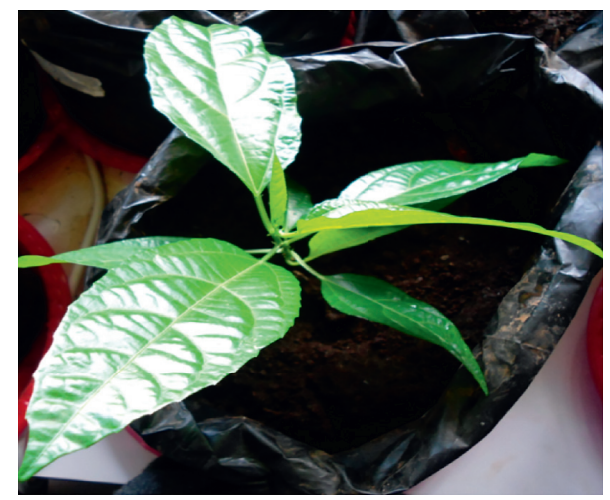

(d)

FIGURE 2: Foliar symptoms at eight weeks after inoculation. Diffused leaf mosaic by CABMV isolate 2 (a), concentrated mosaic, rugose leaf, vein clearing, and deformed leaves by CABMV isolate 1 (b), leaf curl, whole leaf mosaic, leaf deformation, blisters formation, and leaf roll by dual infected virus isolates (c), and healthy plant (d).

\subsection{Determination of Distribution of CABMV in Different} Passion Fruit Plant Parts. There were variations in the distribution of the viruses in the plant parts (Table 3); all the plants which tested positive for general potyvirus antibody were also positive for CABMV antibody. In coinfected plants, $50 \%$ of the leaves and the stems were positive for CABMV, while only $20 \%$ of the roots were positive. In plants inoculated with CABMV isolate $1,50 \%$ of the roots and leaves tested negative for $\mathrm{CABMV}$ and all the stem part tested positive for CABMV. The CABMV isolate 2 had all the leaves and stem testing positive for CABMV, but only $20 \%$ of the roots tested positive (Table 4 ).

\section{Discussion}

The current findings confirm the susceptibility of commercially grown passion fruit species to Cowpea AphidBorne Mosaic Virus (CABMV) and also preliminarily report the presence of two distinct CABMV isolates in Kenya whose disease severity is higher with incidences of coinfection. It is 
TABle 1: Effects of CABMV isolates 1 and 2 and the mixture on P. edulis based on disease symptom severity.

\begin{tabular}{lcc}
\hline Treatment & Mean severity score & $t$-grouping \\
\hline Mixture of CABMV isolate 1 and isolate 2 & 3.2679 & $\mathrm{a}$ \\
CABMV isolate 1 & 2.9107 & $\mathrm{~b}$ \\
CABMV isolate 2 & 2.8393 & $\mathrm{~b}$ \\
Control & 1.0000 & $\mathrm{c}$ \\
\hline
\end{tabular}

Means with the same letter along the column are not significantly different using LSD test at $P=0.05$.

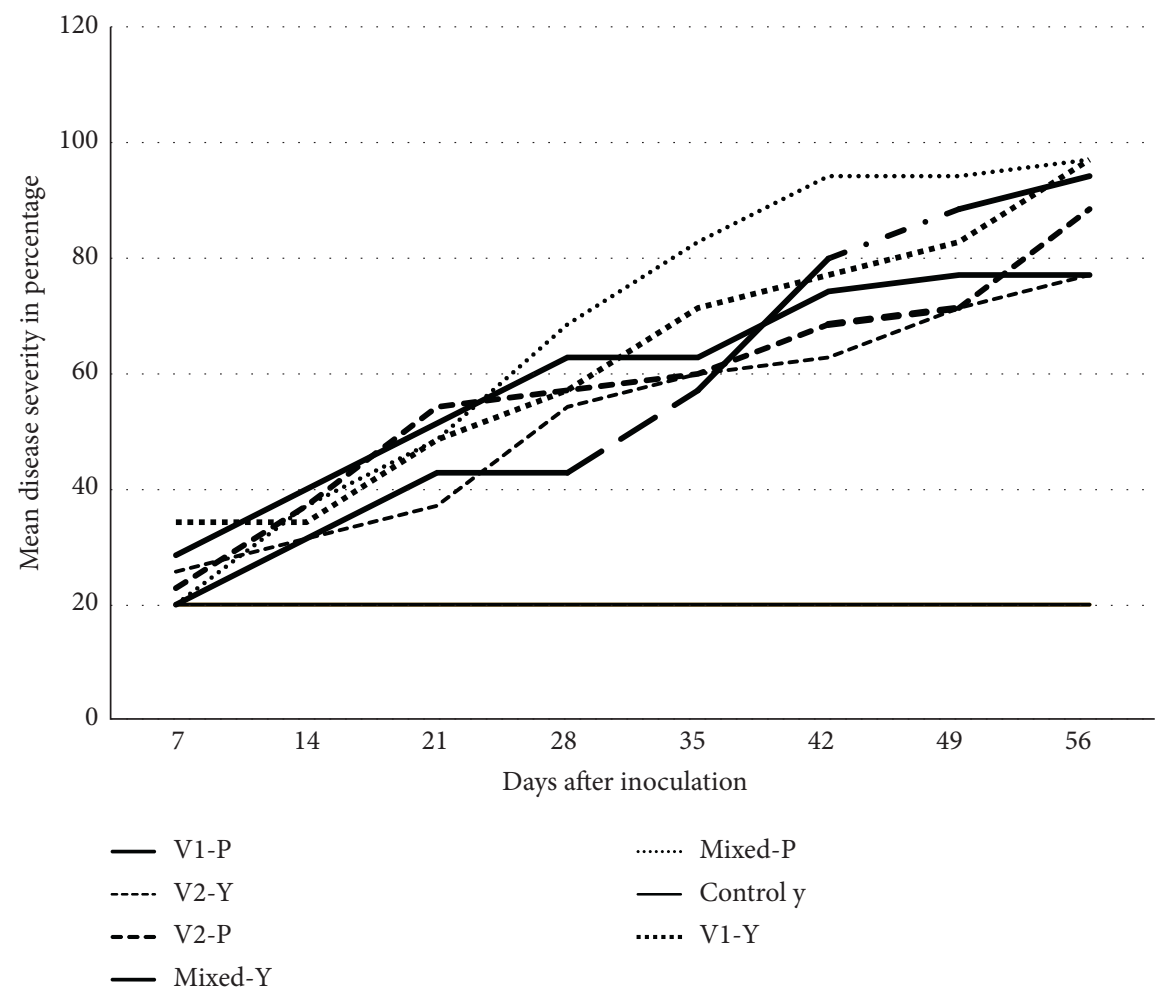

Figure 3: Disease progression in P. ligularis and $P$. edulis 28 days after inoculation. $\mathrm{y}$ is the sweet passion variety $(P$. ligularis), while $\mathrm{p}$ represents the $P$. edulis variety. V1 represents virus isolate $1, \mathrm{~V} 2$ is virus isolate 2 , and mixed represents a combination of CABMV isolate 1 and CABMV isolate 2.

TABle 2: Comparison of $P$. ligularis and $P$. edulis passion fruit reaction to a mixture of the two virus isolates causing woodiness disease.

\begin{tabular}{lcc}
\hline Variety & Mean symptom severity & $t$-grouping \\
\hline$P$. edulis & 2.65 & $\mathrm{a}$ \\
$P$. ligularis & 2.14 & $\mathrm{~b}$ \\
\hline
\end{tabular}

Means with the same letter along the column are not significantly different.

possible that the observed phenomenon can be attributed to alteration of genes which are not affected in a single-virus infection [10] and possible strain differences that need to be studied further.

In the preliminary studies of this experiment where fivemonth-old plants were used as test plants, an average of two plants per treatment showed the viruses symptoms 21 days after inoculation implying that disease severity may be influenced by the age of the plants making older plants less susceptible [17].
The findings of this study show that disease severity dramatically increased due to infection with two CABMV isolates pointing to virus isolate synergy. Changes leading to synergy in plants include an increase of both virus titres, an asymmetric increase of one virus titre with no change in the other, and reduction of one virus titre with the other remaining constant [8]. The results corroborate those of GilSalas et al. [18] which reported synergistic mixed-virus infection among potyviruses. Other similar synergistic diseases include cassava mosaic disease [19] and the maize lethal necrosis disease [20]. The phenomenon of two or more viruses coexisting in the same plant is not rare [21]. The mixed virus can cause either synergistic or antagonistic interaction [8]. The mixture creates unpredictable consequences on disease epidemiology and biology [21]. However, not all cases of coinfection are detrimental to the plant. For instance, a dual infection involving tomato spotted wilt virus and peanut mottle virus does not result in intensification of the symptom severity [22]. 
TABle 3: Determination of potyvirus presence in $P$. edulis plants parts by ACP-ELISA.

\begin{tabular}{|c|c|c|c|}
\hline \multirow[t]{2}{*}{ Inoculum } & \multicolumn{3}{|c|}{$\begin{array}{c}\text { Mean absorbance value of plants at } 405 \mathrm{~nm} \\
\text { wavelength }\end{array}$} \\
\hline & Leaves & Stems & Roots \\
\hline \multirow{4}{*}{ CABMV isolate 1} & 0.134 positive & 0.119 positive & $\begin{array}{l}0.1605 \\
\text { positive }\end{array}$ \\
\hline & 0.286 positive & 0.177 positive & $\begin{array}{c}0.1155 \\
\text { negative }\end{array}$ \\
\hline & 0.267 positive & $\begin{array}{c}0.234 \\
\text { positive }\end{array}$ & $\begin{array}{c}0.225 \\
\text { positive }\end{array}$ \\
\hline & 0.124 positive & $\begin{array}{c}0.1275 \\
\text { positive }\end{array}$ & $\begin{array}{c}0.1585 \\
\text { positive }\end{array}$ \\
\hline \multirow{4}{*}{ CABMV isolate 2} & 0.135 positive & 0.124 positive & $\begin{array}{c}0.1025 \\
\text { negative }\end{array}$ \\
\hline & 0.125 positive & 0.135 positive & $\begin{array}{c}0.1045 \\
\text { negative }\end{array}$ \\
\hline & 0.103 negative & 0.198 positive & $\begin{array}{l}0.4215 \\
\text { positive }\end{array}$ \\
\hline & 0.160 positive & 0.164 positive & 0.176 positive \\
\hline \multirow{4}{*}{$\begin{array}{l}\text { CABMV mix } \\
\text { isolates }\end{array}$} & 0.1145 negative & $\begin{array}{c}0.109 \\
\text { negative }\end{array}$ & $\begin{array}{c}0.105 \\
\text { negative }\end{array}$ \\
\hline & 0.9675 positive & $\begin{array}{c}0.234 \\
\text { positive }\end{array}$ & $\begin{array}{l}1.9605 \\
\text { positive }\end{array}$ \\
\hline & 0.1715 positive & $\begin{array}{c}0.0905 \\
\text { negative }\end{array}$ & $\begin{array}{c}0.1345 \\
\text { positive }\end{array}$ \\
\hline & $\begin{array}{l}1.266 \text { positive } \\
\text { Mean }=0.0585\end{array}$ & 0.161 positive & 0.156 positive \\
\hline
\end{tabular}

Note. Absorbance value at $450 \mathrm{~nm}$. Samples with mean absorbance values higher than two times the negative control average (healthy plant parts), which is 0.117 , were considered positive.

In a mixed-virus infection, some plants maintain the symptoms of the viruses in question, while in others the symptoms are altered. For instance, a combination of pepper golden mosaic virus (PepGMV) and pepper huasteco virus (PHV) elicits different symptoms after interaction [8]. The results of the current study show symptom alteration. The increase of symptoms severity for coinfected plants suggests the presence of cumulative RNA suppressing mechanism from the two virus isolates that facilitate synergism. This phenomenon of symptoms development aggravation in coinfected plants has been reported by Lamichhane and Venturi [9].

In general, the disease severity increased with time in all treatments. However, there was varietal difference in the sweet passion and purple variety in the rate of disease progression. The plants inoculated with the single isolates were the first to be infected compared to the coinfected ones. In fact, coinfected plants first showed symptoms after 14 days of inoculation, while singly infected ones showed symptoms after 7 and 10 days. The plants treated with CABMV isolate 1 were the first to show symptoms followed by CABMV isolate 2 and finally the mixture. This difference in latency period suggests that virus isolate 1 initiates an efficient systemic infection relative to virus isolate 2 . When the two virus isolates were mixed, systemic infection was established after two weeks suggesting that virus isolate 2 interfered with virus isolate 1 kinetics by making it slower. However, since the severity of the disease increased faster in
TABLE 4: Determination of CABMV isolate distribution in P. edulis by DAS-ELISA, absorbance value for CABMV assay indicates the presence or absence of the virus in different organs.

\begin{tabular}{|c|c|c|c|}
\hline $\begin{array}{l}\text { Plant } \\
\text { part }\end{array}$ & Virus type & $\begin{array}{c}\text { Mean absorbance } \\
\text { value }\end{array}$ & $\begin{array}{l}\text { Reaction to } \\
\text { antisera }\end{array}$ \\
\hline \multirow{13}{*}{ Leaves } & \multirow{4}{*}{ CABMV 1} & 0.229 & Positive \\
\hline & & 0.14 & Negative \\
\hline & & 0.141 & Negative \\
\hline & & 0.2145 & Positive \\
\hline & \multirow{4}{*}{ CABMV 2} & 0.3015 & Positive \\
\hline & & 0.4895 & Positive \\
\hline & & 0.239 & Positive \\
\hline & & 0.2545 & Positive \\
\hline & \multirow{4}{*}{ Mixed } & 0.1505 & Negative \\
\hline & & 1.165 & Positive \\
\hline & & 0.1925 & Positive \\
\hline & & 0.683 & Positive \\
\hline & Control & 0.21275 & \\
\hline \multirow{13}{*}{ Stem } & \multirow{4}{*}{ CABMV 1} & 0.3015 & Positive \\
\hline & & 0.4895 & Positive \\
\hline & & 0.239 & Positive \\
\hline & & 0.2545 & Positive \\
\hline & \multirow{4}{*}{ CABMV2 } & 0.1325 & Positive \\
\hline & & 0.373 & Positive \\
\hline & & 0.159 & Negative \\
\hline & & 0.1995 & Positive \\
\hline & \multirow{4}{*}{ Mixed } & 0.2405 & Positive \\
\hline & & 0.164 & Negative \\
\hline & & 0.283 & Positive \\
\hline & & 0.1565 & Negative \\
\hline & Control & 0.186 & \\
\hline \multirow{13}{*}{ Roots } & \multirow{4}{*}{ CABMV 1} & 0.164 & Negative \\
\hline & & 0.1335 & Positive \\
\hline & & 0.2255 & Positive \\
\hline & & 0.1425 & Negative \\
\hline & \multirow{4}{*}{ CABMV 2} & 0.288 & Positive \\
\hline & & 0.3965 & Positive \\
\hline & & 0.3315 & Positive \\
\hline & & 0.1485 & Negative \\
\hline & \multirow{4}{*}{ Mixed } & 0.146 & Negative \\
\hline & & 0.157 & Negative \\
\hline & & 0.149 & Negative \\
\hline & & 0.411 & Positive \\
\hline & Control & 0.225 & \\
\hline
\end{tabular}

Note. Absorbance value at $450 \mathrm{~nm}$. Samples with mean absorbance values higher than two times the negative control average (healthy plant parts) were considered positive.

mixed infection after the initial infection, it implies that virus isolate 2 has a negative influence on isolate 1 during the early phase of infection, but later virus isolate 2 facilitates infection systematically. The difference in disease progression among these virus isolates implies that plant resistance to these viruses is dependent on the mechanism that facilitates movement of the pathogen between cells or those that inhibit the process of a specific virus replication in the tissues [8].

The movement of virus from the inoculated leaves to new leaves is slowed down after a while in singly infected plants due to resistance against the virus [18]. However, in mixedvirus infection, virus movement within the plants increased 
tremendously after the first symptoms. This phenomenon has been attributed to the suppression of the host plant RNA silencing mechanism [23]. Interaction of viruses occurs as a result of complex processes that include negative interference between involved viruses at certain development stages and synergism in other phases [11]. Alves-Júnior [24] reported similar findings to those of a study of an interaction between tomato yellow spot virus and tomato rugose mosaic virus.

All plants inoculated with the virus isolates tested positive in ELISA test. This indicates that the virus isolates used were strains of CABMV or possibly a very close variant, which could also be a causative agent of woodiness disease in Kenya. In addition, it was observed that the isolates induced different symptoms in the plant. CABMV isolate 1 was more severe than virus isolate 2 . The two CABMV isolates 1 and 2 showed unique symptom development in the passion fruit although they belonged to the same virus species. Similar findings have been reported in strains of cassava mosaic disease where different strains were observed to show diverse infection dynamics and contrasting phenotypes [25].

The distribution of CABMV isolate 1 within the plant showed some differences with the other treatments, and this has an implication in detection and sampling. In this case, the plants with leaves testing negative for potyvirus had the stem and roots testing positive. Conventionally, the leaves have been the gold standard for virus detection [26]. However, these results show that the absence of virus in the leaves does not necessarily mean that the plant is virus free. Therefore, a negative leaf test should not be interpreted as a definite diagnosis of this virus isolate. This information helps in the selection of plant parts with high viral load for sampling.

When testing for virus isolate 2 , the virus was widely distributed in the plant; thus all the tissues can be used in detection. However, the virus titre (absorbance) value of the leaves was relatively higher than in the roots and the stem, thus making the leaves the best part for diagnostic purposes. Epidemic outbreaks of woodiness disease causing virus can be attributed to the thorough distribution in the stem, roots, and leaves. This is because the viruses can be acquired by the vectors in any part of the infected plant as they feed.

\section{Conclusion}

The current results have provided a framework for understanding the epidemic of woodiness disease which is currently ongoing in all passion fruit growing areas globally. The disease rapid spread can be attributed to readily available inoculum in all plant parts and increased virus concentration in the plant due to synergistic interaction. This information on the distribution of CABMV in different tissues aids in providing sensitive diagnosis during the early phase of disease development. Therefore, this study outcome is important in the management of passion fruit woodiness disease.

\section{Data Availability}

All data used to support the findings of this study are included within the article.

\section{Conflicts of Interest}

The authors declare that they have no conflicts of interest.

\section{Acknowledgments}

The authors are grateful to the Department of Biological Sciences, Egerton University, for approving this research, and the Department of Biochemistry where viral infection studies were conducted together with the collaborative effort of University of Nairobi and BecA-ILRI through the Swedish International Development Cooperation Agency (Sida) that partly funded the study. Additionally, they are highly indebted to Ms. Sicily Muchira of University of Nairobi and Kenya Plant Inspectorate Services virology staff for guidance accorded when undertaking laboratory work.

\section{References}

[1] Horticulture crops Development Authority [HCDA], Export Crop Report 2013 with Rationalized Statistics, Export Statistics for Fresh Fruits, Flowers and Vegetables for the Year, HCDA, Nairobi, Kenya, 2016.

[2] D. M. S. Freitas and J. A. M. Rezende, "Protection between strains of Papaya ringspot virus: type $\mathrm{w}$ in zucchini squash involves competition for viral replication sites," Scientia Agricola, vol. 65, no. 2, pp. 183-189, 2008.

[3] D. C. Kilalo, F. M. Olubayo, E. M. Ateka, J. C. Hutchinson, and J. W. Kimenju, "Monitoring of Aphid fauna in passion fruit orchards in Kenya," International Journal of Horticulture and Crop Science, vol. 1, pp. 1-18, 2013.

[4] R. L. Amata, M. J. Otipa, M. Waiganjo et al., "Management strategies for fungal diseases in passion fruit production systems in Kenya," Acta Horticulturae, vol. 911, no. 911, pp. 207-213, 2011.

[5] C. A. Baker and L. Jones, "A new potyvirus found in Passiflora incidence in Florida," Plant Disease, vol. 91, no. 2, pp. 226-227, 2007.

[6] M. Ochwo-Ssemakula, T. Sengooba, J. J. Hakiza et al., "Characterization and distribution of a Potyvirus associated with passion fruit woodiness disease in Uganda," Plant Disease, vol. 96, no. 5, pp. 659-665, 2012.

[7] J. Syller and A. Grupa, "The effects of co-infection by differentPotato virus $\mathrm{Y}$ (PVY) isolates on virus concentration in solanaceous hosts and efficiency of transmission," Plant $\mathrm{Pa}$ thology, vol. 63, no. 2, pp. 466-475, 2014.

[8] J. Syller, "Facilitative and antagonistic interactions between plant viruses in mixed infections," Molecular Plant Pathology, vol. 13, no. 2, pp. 204-216, 2012.

[9] J. R. Lamichhane and V. Venturi, "Synergisms between microbial pathogens in plant disease complexes: a growing trend," Frontiers in Plant Science, vol. 06, p. 385, 2015.

[10] R. Froissart, J. Doumayrou, F. Vuillaume, S. Alizon, and Y. Michalakis, "The virulence-transmission trade-off in vector-borne plant viruses: a review of (non-) existing studies," Philosophical Transactions of the Royal Society B: Biological Sciences, vol. 365, no. 1548, pp. 1907-1918, 2010.

[11] I. Rentería-Canett, B. Xoconostle-Cázares, R. Ruiz-Medrano, and R. F. Rivera-Bustamante, "Geminivirus mixed infection on pepper plants: synergistic interaction between PHYVV and PepGMV," Virology Journal, vol. 8, no. 1, p. 104, 2011.

[12] A. A. Tahmasebi, A. Dizadji, and M. Koohi Habibi, "Interaction ofCucumber mosaic virusandBean yellow mosaic 
virusin co-infected plants of bean and broad bean," Archives of Phytopathology and Plant Protection, vol. 46, no. 9, pp. 1081-1092, 2013.

[13] F. Munguti, S. Maina, E. N. Nyaboga et al., "Transcriptome sequencing reveals a complete genome sequence of Cowpea aphid-borne mosaic virus from passion fruit in Kenya," Microbiology Resource Announcements, vol. 8, no. 2, pp. e01607-18, 2019.

[14] Q. S. Novaes and J. A. M. Rezende, "Possible use of indirect das-elisa for screening of passionfruit tolerant to passionfruit woodiness virus," Fitopatologia Brasileira [Brazil], vol. 24, no. 1, pp. 76-79, 1999.

[15] M. F. Clark and A. N. Adams, "Characteristics of the microplate method of enzyme-linked immunosorbent assay for the detection of plant viruses," Journal of General Virology, vol. 34, no. 3, pp. 475-483, 1977.

[16] M. Bar-Joseph and R. Hull, "Purification and partial characterization of sugar beet yellows virus," Virology, vol. 62, no. 2, pp. 552-562, 1974.

[17] M. A. Sevik and E. Kose-Tohumcu, "The ELISA analysis results in tomato [Lycopersicon esculentum Mill.] seed health testing for Tobacco mosaic virus," Zemdirbyste Agriculture, vol. 98, pp. 301-306, 2011.

[18] F. M. Gil-Salas, J. Peters, N. Boonham, I. M. Cuadrado, and D. Janssen, "Yellowing disease in zucchini squash produced by mixed infections of Cucurbit yellow stunting disorder virus and Cucumber vein yellowing virus," Phytopathology, vol. 101, no. 11, pp. 1365-1372, 2011.

[19] V. N. Fondong, “The search for resistance to cassava mosaic geminiviruses: how much we have accomplished, and what lies ahead," Frontiers in Plant Science, vol. 8, p. 408, 2017.

[20] N. L. Mwando, A. Tamiru, J. O. Nyasani et al., "Maize chlorotic mottle virus induces changes in host plant volatiles that attract vector thrips species," Journal of Chemical Ecology, vol. 44, pp. 681-689, 2018.

[21] S. F. Elena, "Evolutionary constraints on emergence of plant RNA viruses," Recent Advances in Plant Virology, vol. 24, pp. 283-300, 2011.

[22] K. Hoffmann, S. M. Geske, and J. W. Moyer, "Pathogenesis of tomato spotted wilt virus in peanut plants dually infected with peanut mottle virus," Plant Disease, vol. 82, no. 6, pp. 610-614, 1998.

[23] A. K. Singh, N. Kushwaha, and S. Chakraborty, "Synergistic interaction among begomoviruses leads to the suppression of host defense-related gene expression and breakdown of resistance in chilli," Applied Microbiology and Biotechnology, vol. 100, no. 9, pp. 4035-4049, 2016.

[24] M. Alves-Júnior, P. Alfenas-Zerbini, E. C. Andrade et al., "Synergism and negative interference during co-infection of tomato and Nicotiana benthamiana with two bipartite begomoviruses," Virology, vol. 387, no. 2, pp. 257-266, 2009.

[25] B. L. Patil and C. M. Fauquet, "Cassava mosaic geminiviruses: actual knowledge and perspectives," Molecular Plant $\mathrm{Pa}$ thology, vol. 10, no. 5, pp. 685-701, 2009.

[26] C. Lacroix, K. Renner, E. Cole, E. W. Seabloom, E. T. Borer, and C. M. Malmstrom, "Methodological guidelines for accurate detection of viruses in wild plant species," Applied and Environmental Microbiology, vol. 82, no. 6, p. 1966, 2016. 